that expansion of services which would be rendered possible by an increase in its membership to include every chemical manufacturer in Great Britain. In his speech at the annual general meeting held on October 8, the chairman referred to the successful outcome of many of the enterprises which the Association has undertaken in the interests of its members, including in his survey a reference to the measures which are being undertaken to protect our factories against air attacks in the unfortunate event of war. The Association has also participated in investigations concerning the detection of toxic gases in industry. It is announced that the first pamphlet of the series, that dealing with hydrogen sulphide, will shortly be published by the Department of Scientific and Industrial Research. Dr. E. F. Armstrong was re-elected president for the coming year.

\section{The Velocity of Light}

From time to time, Mr. M. E. J. Gheury de Bray has published in the columns of NATURE communications on this subject. He has now brought together the results of his investigations in an article published in Isis (25, 2; September 1936), entitled "The Velocity of Light: History of its Determination from 1849 to 1933". Reprints of the article have been prepared and can be obtained from Mr. Gheury de Bray, Imperial Patent Service, First Avenue House, High Holborn, W.C.1 (price 1s.).

\section{Pavlov Institute of Aviation Medicine}

As successful flying over long distances or to high altitudes depends not only on the efficiency of the aeroplane and the skill of the pilot but also to some extent on such minor details as the clothing and diet of the pilot, the structure of the cabin, etc., an Institute of Aviation Medicine dedicated to Prof. I. P. Pavlov was organized about a year ago in Soviet Russia. The laboratories of the Institute make tests of clothing, oxygen apparatus and anti-noise helmets, and study the problem of producing light, warm and comfortable clothing for airmen. Oxygen apparatus used in flights is produced under the direct supervision of the Institute, and the fitness of airmen wishing to ascend to high altitudes is tested in the Institute's barometric chamber.

\section{Early Photographic Instruments}

Some of the earliest instruments in the history of photography have just been acquired by the Science Museum, South Kensington, on loan from the Royal Photographic Society of Great Britain. They include three instruments used by Fox Talbot, the inventor of the first paper photographic process : (1) A camera lucida, the use of which on the shores of Lake Como in 1833 first suggested to him that the invention of a sensitive paper would record such scenes more perfectly than sketches made by hand. This is the instrument mentioned in his "Pencil of Nature", published in 1844. (2) Fox Talbot's solar microscope, with which the earliest photomicrographs on paper were produced. (3) A Culpepper type microscope, c. 1820. With other instruments and specimens which have recently been acquired and are in course of classification prior to exhibition, the representation of Fox Talbot's work in photography bids fair to be complete.

\section{"Annual Tables of Constants and Numerical Data"}

THe publication of the "Annual Tables" having lagged behind schedule since vol. $10(1930)$, the new managing committee (Institut de Chemie, 11 Rue Pierre Curie, Paris, $\left.5^{\mathrm{e}}\right)$ proposes to make up for it by publishing the data for 1931-36 in a more condensed form and more critically edited, in separate fascicules by subjects, partly separately for 1931-34 and 1935-36 and partly for the whole period 1931-36. The set of these fascicules will form vols. 11 and 12 of the "Annual Tables". 'This programme is to be completed in 1937: the numerical material published in the "Annual Tables" will then be brought up to date. In addition, an index volume by substances for vols. 6-10 (1923-30), like that published for vols. 1-5 (1910-22), is to appear towards the end of this year. A new index volume by substances will be prepared for vols. 11 and 12 , to be published in 1937. The Committee would welcome inquiries about the "Tables", and state that the back numbers have now been greatly reduced in price. The new fascicules are being issued at a very modest price, which will place them at the disposal of all scientific workers likely to need them in their investigations. The preparation of the "Annual Tables", which is a purely scientific and non-profit-making undertaking, is a worthy task deserving the active support of men of science in securing their prompt publication.

\section{Dr. A. H. Mackenzie}

IN announcing the death of Dr. A. H. Mackenzie, in NATURE of October 10, he was described, following "Who's Who", as "Pro-Vice-Chancellor of the Osmania University, Hyderabad". Prof. M. S. Ahmed writes to say that the correct official title is "Pro-ViceChancellor of and Special Propagandist for the Osmania University of Hyderabad". He adds : "Dr. Mackenzie was appointed to the position of ProVice-Chancellor of the Osmania University in which capacity he had to work six months in the year at Hyderabad, and the remaining six months he had to spend in Great Britain in doing special propaganda in the British Universities on behalf of the Osmania University".

\section{A Nova in Sagittarius}

THE discovery of a nova on October 6 (the third to be discovered since last June) has been announced by telegram from the International Astronomical Union's Bureau at Copenhagen. The position is given as R.A. $18^{\mathrm{h}} 4 \cdot 5^{\mathrm{m}}$ : Dec. $34^{\circ} 21^{\prime}$ south : magnitude 6 on Oct. $6^{\text {d }} 0^{\mathrm{h}}$ U.T. This position places the nova in the constellation of Sagittarius and roughly midway between the 3rd magnitude stars, $\gamma$ Sagittarii and $\eta$ Sagittarii. The discoverer is Mr. C. Jackson, 